\title{
Pengaruh Motivasi Orang Tua Terhadap Perilaku Sosial Anak Autis Di Sekolah Dasar Mulia Bhakti Makassar
}

\author{
Renny Pritama Dewi Sannang, Simon A. Tarigan
}

\begin{abstract}
Abstrak
Latar belakang dalam penelitian ini adalah pengaruh motivasi orang tua terhadap perilaku sosial anak autis. Autis merupakan suatu gangguan atau kelainan pada struktur otak atau fungsi otak yang dapat dideteksi sejak usia 12 bulan atau satu tahun. Terdapat gejala-gejala yang menunjukkan bahwa seseorang mengalami autisme dapat dilihat pada perilaku sosialnya, dimana ada hambatan atau kesulitan dalam berkomunikasi dan kesulitan dalam berinteraksi atau berhubungan dengan orang lain.

Motivasi adalah rangsangan atau dorongan yang dapat mendorong serta memengaruhi seseorang baik itu dari luar maupun dari dalam diri sendiri. Setiap anak membutuhkan motivasi termasuk juga anak autis, dimana motivasi berfungsi untuk membantu mencapai suatu tujuan tertentu. Oleh karena itu, penelitian ini dibuat untuk mengetahui apakah pemberian motivasi dari orang tua dapat mempengaruhi perilaku sosial pada anak autis.

Dalam penelitian ini penulis mengambil sampel sebanyak dua puluh (20) anak autis di Sekolah Dasar Mulia Bhakti Makassar dengan rentangan usia 7-13 tahun. Penelitian ini dilakukan dengan memberikan angket kepada sebanyak dua puluh (20) orang tua yang memiliki anak autis di Sekolah Dasar Mulia Bhakti Makassar yang berumur 7-13 tahun. Penelitian yang dilakukan adalah penelitian kuantitatif dengan menggunakan SPSS untuk mengetahui korelasi atau hubungan motivasi orang tua dan perilaku sosial anak autis.

Hasil data yang diperoleh menunjukkan bahwa motivasi orang tua mempunyai pengaruh terhadap perilaku sosial anak autis. Berdasarkan tabel korelasi didapatkan hasil mengenai besar korelasi atau hubungan antara variabel motivasi orang tua dengan perilaku sosial anak autis sebesar 0.495 , dan ini menunjukkan korelasi atau hubungan yang sedang antara motivasi orang tua dengan perilaku sosial anak autis.
\end{abstract}

Kata-kata Kunci: Motivasi Orang Tua, Perilaku Sosial, Anak Autis.

\section{Pendahuluan}

\section{Latar Belakang Masalah}

Anak berkebutuhan khusus atau yang disingkat dengan ABK merupakan anak-anak yang memerlukan pelayanan yang spesifik, yang berbeda dengan anak pada umumnya. ${ }^{1}$

${ }^{1}$ Laili S. Cahaya, Adakah ABK di Kelasku, Bagaimana Guru Mengenali ABK di Sekolah (Yogyakarta: Familia, 2013), 5, diakses 19 Februari 2018, https://books.google.co.id/ [online]. 
Anak berkebutuhan khusus merupakan anak-anak dengan karakteristik yang khusus yang tidak dimiliki oleh anak-anak lain pada umumnya.

Karakteristik khusus yang dimiliki oleh anak-anak ABK ini, yaitu mereka mengalami kelainan atau penyimpangan dalam segi fisik, mental, emosi, dan sosial, sehingga mereka memerlukan perlakuan atau pelayanan yang khusus. Dalam buku Special Education for Special Children menggolongkan anak berkebutuhan khusus menjadi tiga kategori, yakni anak-anak dengan masalah atau gangguan pendengaran (tunarungu), anak-anak dengan masalah atau gangguan penglihatan (tunanetra), dan anak-anak dengan masalah dalam pembelajaran. ${ }^{2}$ Geniofam menggolongkan anak berkebutuhan khusus menjadi beberapa kategori, yakni anak-anak dengan masalah atau gangguan pendengaran (tunarungu), anakanak dengan masalah atau gangguan penglihatan (tunanetra), anak-anak dengan keterbelakangan mental (tunagrahita), anak-anak dengan masalah atau gangguan gerak (tunadaksa), anak-anak dengan masalah dalam mengendalikan emosi dan kontrol sosial (tunalaras), anak-anak dengan masalah dalam pembelajaran seperti diskalkulia, disgrafia, dan disleksia, serta anak-anak dengan gangguan perilaku seperti autis, ADHD (Attention Deficit Hyperactive Disorders), dan anak berbakat. ${ }^{3}$

Dalam tulisan ini akan membahas lebih khusus mengenai anak autis. Autisme terjadi pada 5 dari setiap 10.000 kelahiran, dan jumlah penderita autis laki-laki empat kali lebih besar atau lebih banyak dibandingkan dengan jumlah penderita perempuan. Namun, apabila perempuan mengalaminya, maka penderitaannya akan jauh lebih parah dibandingkan dengan laki-laki. ${ }^{4}$

Autis merupakan gangguan perkembangan pervasif pada anak yang ditandai dengan adanya gangguan dan keterlambatan dalam bidang kognitif, bahasa, perilaku, komunikasi, dan juga interaksi sosial. Autis berasal dari kata auto yang berarti sendiri. Jadi, kata autis ini ditujukan kepada orang yang mempunyai gejala hidup di dunianya sendiri. ${ }^{5}$

Dalam perilaku sosial anak autis memiliki perilaku yang cenderung berbeda dari anak normal, dimana anak autis mengalami gangguan bahasa, komunikasi, dan interaksi sosial, karena anak autis mengalami gangguan bahasa, sehingga secara otomatis menyebabkan anak mengalami kesulitan dalam komunikasi dan juga interaksi sosial. ${ }^{6}$ Tanda yang ditunjukkan oleh anak autis akibat gangguan tersebut ialah anak autis akan cenderung menyendiri, menghindari kontak dengan orang lain, dan lebih menyibukkan diri dengan benda-benda mati atau mainan kesukaannya. ${ }^{7}$

\footnotetext{
2 Jamila K. A. Muhammad, Special Education for Special Children (Jakarta: Hikmah, 2008), 15, diakses 19 Maret 2018, https://books.google.co.id/ [online].

${ }^{3}$ Stella Olivia, Pendidikan Inklusi untuk Anak-Anak Berkebutuhan Khusus (Yogyakarta: ANDI, 2017), 2. Stella Olivia mengutip Geniofam, Mengasuh dan Mensukseskan Anak Berkebutuhan Khusus (Yogyakarta: Garai Ilmu, 2010).

${ }^{4}$ Mirza Maulana, Anak Autis: Mendidik Anak Autis dan Gangguan Mental Lain Menuju Anak Cerdas dan Sehat (Jogjakarta: Katahati, 2007), 11.

5 Tri Gunadi, Mereka Pun Bisa Sukses (Jakarta: Penebar Plus $\left.{ }^{+}, 2011\right), 84$.

${ }^{6}$ Isroatul Marya Ulfah dan Budiyanto, "Interaksi Sosial Peserta Didik Autis di Sekolah Inklusif," Jurnal Pendidikan Khusus 7, no. 4 (2015):2, diakses 12 Agustus 2018, http://id.portalgaruda.org/?ref=author\&mod=profile \&id=522304.

${ }^{7}$ Ratna Wahyu Widuri, "Penanganan Kemampuan Interaksi Sosial Anak Autis," Jurnal Pendidikan Khusus 3, no. 3 (2013):2, diakses 12 Agustus 2018, http://jurnalmahasiswa.unesa.ac.id/index.php/jurnalpendidikan-khusus/article/view/3386/6045.
} 
Anak autis bukan hanya memerlukan penanganan dari tenaga kesehatan saja, namun juga yang paling berperan dalam penanganan anak autis, yakni orang tua. Peran aktif orang tua untuk memberikan dukungan kepada penyandang autisme merupakan salah satu faktor penting dalam proses penyembuhan sang anak. ${ }^{8}$

Seperti yang dikemukakan oleh Asmika, dkk, Afriyet Susanti dan Sri Indiyah juga mengatakan bahwa peran aktif dari orang tua dalam mengasuh dan menangani autisme sangat penting untuk perkembangan perilaku sang anak. Orang tua yang secara aktif mengasuh dan menangani anak autis, serta memberikan motivasi atau dukungan kepada sang anak, akan dapat memengaruhi perkembangan perilaku anak autis. ${ }^{9}$

Sejalan dengan masalah dalam perilaku sosial yang di alami oleh anak penyandang autis, maka di sinilah peran penting dari orang tua, dimana sebagai orang tua seyogyanya dapat mengasuh, membimbing dan juga memberikan motivasi kepada anak yang menyandang autisme. Sebab motivasi merupakan suatu dorongan atau rangsangan yang diberikan oleh orang tua kepada anak penyandang autisme, dimana dorongan atau rangsangan yang diberikan ini bertujuan agar perilaku anak autis terutama dalam perilaku sosialnya dapat mengalami perkembangan atau perubahan.

Pemberian motivasi orang tua berkaitan dengan perilaku sosial anak autis dapat berupa pemberian pujian, hadiah, memotivasi lewat contoh yang diberikan orang tua bagaimana cara bersosialisasi yang baik dan benar dengan orang lain, memotivasi anak lewat kesukaannya, dan juga dapat berupa pemberian hukuman yang tepat dan bijak. Pemberian motivasi yang diberikan oleh orang tua ini diharapkan dapat mengatasi masalah perilaku sosial pada anak autis, sehingga anak autis dapat berkomunikasi dan berinteraksi dengan baik dengan orang lain yang berada di sekitarnya.

\section{Pokok Masalah}

Dari latar belakang yang telah dipaparkan di atas, maka yang menjadi pokok masalah dari penelitian ini ialah bagaimanakah pengaruh motivasi orang tua terhadap masalah perilaku sosial anak autis di Sekolah Mulia Bhakti Makassar.

\section{Tujuan Penelitian}

Tujuan penelitian ini adalah untuk menganalisis pengaruh motivasi orang tua terhadap masalah perilaku sosial anak autis di Sekolah Mulia Bhakti Makassar pada anak usia 7-13 tahun.

\section{Manfaat Penelitian}

Pertama, kegunaan teori. Manfaat penelitian ditinjau dari kegunaan teorinya, yakni hasil penelitian ini diharapkan dapat memberikan sumbangan dalam pengembangan teoriteori dan juga pengembangan konsep mengenai pengaruh motivasi orang tua terhadap masalah perilaku sosial anak autis.

\footnotetext{
${ }^{8}$ Asmika, Sri Andarini, dan Ririn Puji Rahayu, "Hubungan Motivasi Orang Tua untuk Mencapai Kesembuhan Anak dengan Tingkat Pengetahuan tentang Penanganan Anak Penyandang Autisme dan Spektrumnya," Jurnal Kedokteran Brawijaya XXII, no. 2 (Agustus 2006):90, diakses 12 Agustus 2018, http://jkb.ub.ac.id/index.php/jkb/article/viewFile/230/222.

${ }^{9}$ Afriyet Susanti dan Sri Indiyah, "Pengalaman Orang Tua Merawat Anak Autisme Usia 15-17 Tahun," Journal of Holistic Nursing Science 5, no. 1 (Februari 2018):2-3, diakses 12 Agustus 2018, http://journal.ummgl.ac.id/index.php/nursing/article/view/1874.
} 
Kedua, kegunaan praktis. Manfaat penelitian ditinjau dari kegunaan praktisnya bagi: (1) Orang tua, penelitian ini diharapkan dapat menjadi pedoman untuk dapat membantu orang tua dalam mengatasi masalah perilaku sosial anak yang menyandang autisme. (2) Gereja dan sekolah, penelitian ini diharapkan dapat memberikan pemahaman bagi gereja dan sekolah tentang autisme dan pentingnya pemberian motivasi dalam mengatasi masalah perilaku sosial yang dihadapi oleh anak autis dan diharapkan gereja dan sekolah dapat saling bekerja sama dengan orang tua dalam membantu mengatasi masalah perilaku sosial pada anak penyandang autisme. (3) Para pembaca, penelitian ini diharapkan dapat menambah wawasan kepada setiap pembaca berkaitan dengan anak-anak dengan kebutuhan khusus terlebih untuk anak-anak penyandang autisme.

Ketiga, untuk memenuhi salah satu persyaratan akademik dalam memperoleh gelar kesarjanaan Stratum Satu (S1) program studi Pendidikan Agama Kristen pada Sekolah Tinggi Theologia Jaffray Makassar.

\section{Metode Penelitian}

Adapun metode penelitian yang digunakan dalam penelitian ini untuk mendapatkan data yang diperlukan, adalah:

Pertama, angket yang dikelola secara kuantitatif untuk mengetahui hubungan antara motivasi yang diberikan oleh orang tua terhadap masalah perilaku sosial pada anak autis di Sekolah Mulia Bhakti Makassar.

Kedua, metode library research atau pengumpulan data melalui studi kepustakaan, yakni penulis mencari dan membaca beberapa jurnal dan buku yang berkaitan dengan judul yang akan penulis bahas.

\section{Batasan Penelitian}

Dalam penulisan ini, penulis membatasi hanya pada pengaruh motivasi orang tua terhadap masalah perilaku sosial anak autis dengan rentangan usia 7-13 tahun di Sekolah Dasar Mulia Bhakti Makassar.

\section{Kesimpulan}

Berdasarkan pembahasan yang telah diuraikan dari Bab I sampai dengan Bab IV, maka dapat disimpulkan bahwa:

Pertama, dari hasil penelitian yang dilakukan, diperoleh hasil bahwa sebanyak dua puluh orang tua yang memiliki anak autis di Sekolah Mulia Bhakti Makassar, dan kedua puluh orang tua di sana semuanya dapat menerima kondisi anak. Faktor penerimaan orang tua merupakan faktor yang sangat penting untuk membawa perubahan terhadap perilaku sosial anak autis. Orang tua harus dapat menerima kenyataan bahwa sang anak menyandang autisme dan dapat menganggap bahwa anak autis juga merupakan anugerah yang diberikan Allah bagi orang tua. Apabila orang tua tidak dapat menerima kondisi sang anak, maka orang tua tidak akan pernah bisa memberikan dukungan atau motivasi kepada anak.

Kedua, dari hasil skor rata-rata motivasi orang tua dan perilaku sosial anak autis, diperoleh nilai untuk motivasi orang tua sebesar 20,25 dan nilai untuk perilaku sosial anak autis sebesar 17,2 dari dua puluh orang tua yang diteliti. Dari hasil skor inilah disimpulkan bahwa orang tua yang memiliki anak autis di Sekolah Mulia Bhakti Makassar memberikan motivasi secara aktif kepada anak autis dan karena pemberian motivasi yang diberikan secara 
aktif itulah, terdapat perubahan perilaku sosial pada anak autis. Apabila orang tua memiliki anak autis, maka orang tua perlu untuk memberikan motivasi secara aktif atau terus menerus kepada sang anak agar dapat membawa pengaruh positif bagi perkembangan perilaku sosial sang anak, dan sebaliknya apabila orang tua jarang atau tidak pernah memberikan motivasi kepada anak penyandang autisme, maka perkembangan perilaku sosial anak autis akan mengalami penurunan.

Ketiga, dari hasil perhitungan pada tabel anova dan tabel coefficients diperoleh nilai F hitung sebesar 5,844 dan nilai sig sebesar 0,026. Hasil perhitungan ini bertujuan untuk mengetahui apakah motivasi orang tua berpengaruh secara signifikan (nyata) terhadap perilaku sosial anak autis atau tidak, dan untuk mengetahui kesignifikanan tersebut dilakukan uji hipotesis, dimana jika nilai $F$ hitung lebih besar dari $F$ tabel dan nilai sig lebih kecil dari nilai alpha $(0,05)$ maka variabel $\mathrm{X}$ berpengaruh secara signifikan (nyata) terhadap variabel Y. Nilai F hitung sebesar 5,844 memiliki nilai yang lebih besar dari nilai $F$ tabel, yakni 4,41 dan nilai sig 0,026 memiliki nilai yang lebih kecil dibandingkan dengan nilai alpha 0,05. Maka, hasil yang diperoleh inilah dapat disimpulkan bahwa motivasi orang tua berpengaruh secara signifikan atau nyata terhadap perilaku sosial sang anak. Dari hasil perhitungan $\mathrm{R}$ Square pada tabel model summary diperoleh nilai 0,245 dimana nilai R Square di kali dengan $100 \%$, maka hasilnya $24,5 \%$. Hasil $24,5 \%$ inilah merupakan besar kontribusi motivasi orang tua terhadap perilaku sosial anak autis. Walaupun hasil persentasi yang diperoleh kecil dan berada di bawah 50\%, namun hasil yang diperoleh secara statistika adalah signifikan, maka dapat dikatakan bahwa motivasi orang tua mempunyai pengaruh yang signifikan (nyata) terhadap perkembangan perubahan perilaku sosial anak autis. Oleh karena itu, sebagai orang tua yang memiliki anak autis sangat perlu untuk selalu memberikan dukungan atau motivasi bagi anak-anak autis, sebab motivasi orang tua akan dapat membawa pengaruh yang signifikan (nyata) bagi perubahan perilaku sosial sang anak, dan perubahan perilaku ini dapat dilihat ketika anak autis sudah memiliki ketertarikan untuk bersosialisasi atau berinteraksi dengan orang lain.

\section{Kepustakaan}

Asmika, Sri Andarini, Ririn Puji Rahayu. "Hubungan Motivasi Orang Tua untuk Mencapai Kesembuhan Anak dengan Tingkat Pengetahuan tentang Penanganan Anak Penyandang Autisme dan Spektrumnya." Jurnal Kedokteran Brawijaya XXII, No. 2 (Agustus 2006):90-94. Diakses 12 Agustus 2018.

http://jkb.ub.ac.id/index.php/jkb/article/viewFile/230/222.

Best, Brin. Strategi Percepatan Belajar. Jakarta: Esensi Erlangga Group, 2011.

Boham, Sicillya E. "Pola Komunikasi Orang Tua dengan Anak Autis." Jurnal Acta Diurna

2, No. 4 (2013):1-18. Diakses 28 April 2018. https://ejournal.unsrat.ac.id/index.php/actadiurna/article/view/2886/2436

Capehart, Jody. Cherishing and Challenging Your Children. Jakarta: Metanoia, 2012.

Ezmar dan Ramli. "Bahasa Anak Autis pada SLB Cinta Mandiri Lhoksumawe." Artikel Autis

2, No. 2 (Juli-Desember 2014):1-18. Diakses 18 Juni 2018. 
http://download.portalgaruda.org/article.php?article=293316\&val=6354\&title=Bahas a\%20Anak\%20Autis\%20pada\%20SLB\%20Cinta\%20Mandiri\%20Lhoksumawe.

Geniofam. Mengasuh dan Mensukseskan Anak Berkebutuhan Khusus. Yogyakarta: Garai Ilmu, 2010.

Gulo, W. Metodologi Penelitian. Jakarta: Grasindo, 2008.

Gunadi, Tri. Mereka Pun Bisa Sukses. Jakarta: Penebar Plus ${ }^{+}, 2011$.

Maruanaya, Vita, DAN Weismann, Ivan. "Peran Orang Tua Terhadap Perkembangan Pribadi Remaja Atas Pemanfaatan Internet di Kalangan Remaja di SMU Advent Makassar" Jurnal Jaffray [Online], Volume 8 Nomor 1 (1 April 2010).

Maulana, Mirza. Anak Autis: Mendidik Anak Autis dan Gangguan Mental Lain Menuju Anak Cerdas dan Sehat. Jogjakarta: Katahati, 2007.

Nawawi, M., Martini Hadari. Instrumen Penelitian Bidang Sosial. Yogyakarta: Gadjah Mada University Press, 1992.

Nisrima, S., Muhammad Yunus, Erna Hayati. "Pembinaan Perilaku Sosial Remaja Penghuni Yayasan Islam Media Kasih Kota Banda Aceh.” Jurnal Ilmiah Pendidikan Kewarganegaraan 1, No. 1 (Agustus 2016):192-204. Diakses 28 Mei 2018. https://media.neliti.com/media/publications/187670-ID-pembinaan-perilaku-sosialremaja-penghun.pdf.

Nugraheni, S. A. "Menguak Belantara Autisme." Buletin Psikologi 20, No. 1-2 (September 2012):9-17. Diakses 11 April 2018.

https://jurnal.ugm.ac.id/buletinpsikologi/article/viewFile/11944/8798.

Nur'aeni. Psikologi Pendidikan Anak Berkebutuhan Khusus. Purwokerto: UMP Press, 2017.

Olivia, Stella. Pendidikan Inklusi untuk Anak-Anak Berkebutuhan Khusus. Yogyakarta: Andi, 2017.

Santrock, John W. Psikologi Pendidikan. Jakarta: Salemba Humanika, 2014.

Selan, Ruth F. Pedoman Pembinaan Warga Jemaat. Bandung: Yayasan Kalam Hidup, 1994.

Subagyo, Andreas B. Pengantar Riset Kuantitatif \& Kualitatif Termasuk Riset Teologi dan Keagamaan. Bandung: Yayasan Kalam Hidup, 2004.

Sumantri, Mohamad S. Strategi Pembelajaran Teori dan Praktik di Tingkat Pendidikan Dasar. Jakarta: Rajawali Pers, 2016.

Surbakti, Ronny T. "Pengaruh Motivasi Kerja Terhadap Kinerja Karyawan Golongan 1 di Universitas Katolik Parahyangan.” E-Journal Graduate Unpar 1, No. 2 (2014):211232. Diakses 1 Mei 2018.

https://media.neliti.com/media/publications/184121-ID-pengaruh-motivasi-kerjaterhadap-kinerja.pdf.

Suryati dan Rahmawati. "Pengaruh Terapi Bermain Terhadap Interaksi Sosial Anak Autis di SDLB Prof. Dr. Sri Soedewi Masjchun Sofwan, SH Jambi Tahun 2014.” Jurnal Ilmiah 16, No. 1 (2016):142-147. Diakses 21 Mei 2018.

https://media.neliti.com/media/publications/225580-pengaruh-terapi-bermainterhadap-interak-83f52a5f.pdf

Susanti, A., Sri Indiyah. "Pengalaman Orang Tua Merawat Anak Autisme Usia 15-17 Tahun.” Journal of Holistic Nursing Science 5, No. 1 (Februari 2018):1-13. Diakses 12 Agustus 2018.

http://journal.ummgl.ac.id/index.php/nursing/article/view/1874. 
Susanto, Sigit E. "Penerimaan Orang Tua terhadap Kondisi Anaknya yang Menyandang Autisme di Rumah Terapis Little Star.” Jurnal Psikosains 9, No. 2 (Agustus 2014):140152. Diakses 13 Agustus 2018.

http://journal.umg.ac.id/index.php/psikosains/article/download/247/199/.

Suteja, Jaja. "Bentuk dan Metode Terapi Terhadap Anak Autisme Akibat Bentukan Perilaku Sosial.” Jurnal Edueksos 3, No. 1 (Januari-Juni 2014):119-133. Diakses 17 April 2018. http://id.portalgaruda.org/index.php?ref=browse \&mod=viewarticle\&article=446822 .

Suteja, J., Ruwanti Wulandari. "Bentuk dan Model Terapi Terhadap Anak-Anak Penyandang Autisme (Keterbelakangan Mental)." Jurnal Scientiae Educatia 2, No. 1 (April 2013):113-124. Diakses 15 April 2018.

http://download.portalgaruda.org/article.php?article=447126\&val=9461\&title=BENT UK\%20DAN\%20MODEL\%20TERAPI\%20TERHADAP\%20ANAKANAK\%20PENYANDANG\%20AUTISME\%20(KETERBELAKANGAN\%20MEN TAL).

Thompson, Jenny. Memahami Anak Berkebutuhan Khusus. Jakarta: Esensi Erlangga Group, 2014.

Tiro, Muhammad A. Analisis Korelasi dan Regresi. Makassar: Andira Publisher, 2010.

Tripp, Tedd. Shepherding a Child's Heart: Menggembalakan Anak Anda. Malang: Gandum Mas, 2002.

Ulfah, Isroatul M., Budiyanto. "Interaksi Sosial Peserta Didik Autis di Sekolah Inklusif." Jurnal Pendidikan Khusus 7, No. 4 (2015):1-8. Diakses 12 Agustus 2018. http://id.portalgaruda.org/?ref=author\&mod=profile\&id=522304.

Uno, Hamzah B., Nina Lamatenggo. Tugas Guru dalam Pembelajaran: Aspek yang Mempengaruhi. Jakarta: Bumi Aksara, 2016.

Wadi, Elsyana, DAN Selfina, Elisabet. "Peran Orang Tua Sebagai Keluarga Cyber Smart Dalam Mengajarkan Pendidikan Kristen Pada Remaja GKII Ebenhaezer Sentani Jayapura Papua" Jurnal Jaffray [Online], Volume 14 Nomor 1 (14 Maret 2016).

Wahab, Rohmalina. Psikologi Belajar. Jakarta: Rajawali Press, 2016.

Wahana Komputer. Panduan Praktis SPSS 20. Yogyakarta: Andi, 2012.

Wahjosumidjo. Kepemimpinan dan Motivasi. Jakarta: Ghalia Indonesia, 1987.

Widuri, Ratna W. "Penanganan Kemampuan Interaksi Sosial Anak Autis." Jurnal Pendidikan Khusus 3, No. 3 (2013):1-11. Diakses 11 April 2018. http://jurnalmahasiswa.unesa.ac.id/index.php/jurnal-pendidikankhusus/article/view/3386/5673.

Wijanarko, A., Annastasia Ediati. "Penerimaan Diri pada Orang Tua yang Memiliki Anak Skizofrenia." Jurnal Empati 5, No. 3 (Agustus 2016):424-429. Diakses 13 Agustus 2018. https://media.neliti.com/media/publications/71041-ID-none.pdf.

Wijaya, Hengki (ed.). Metodologi Penelitian Pendidikan Teologi. Makassar: Sekolah Tinggi Theologia Jaffray, 2016. 